\title{
FARMERS' AWARENESS REGARDING DEFORESTATION AT JALMA UNION OF BATIAGHATA UPAZILA UNDER KHULNA DISTRICT OF BANGLADESH
}

\author{
Shipra Mondol, Archona Mollick, Mohammad Bashir Ahmed and \\ Md. Matiul Islam*
}

Agrotechnology Discipline, Khulna University, Khulna-9208, Bangladesh.

*Corresponding author: Dr. Md. Matiul Islam; E-mail: matiul_rubel@yahoo.com

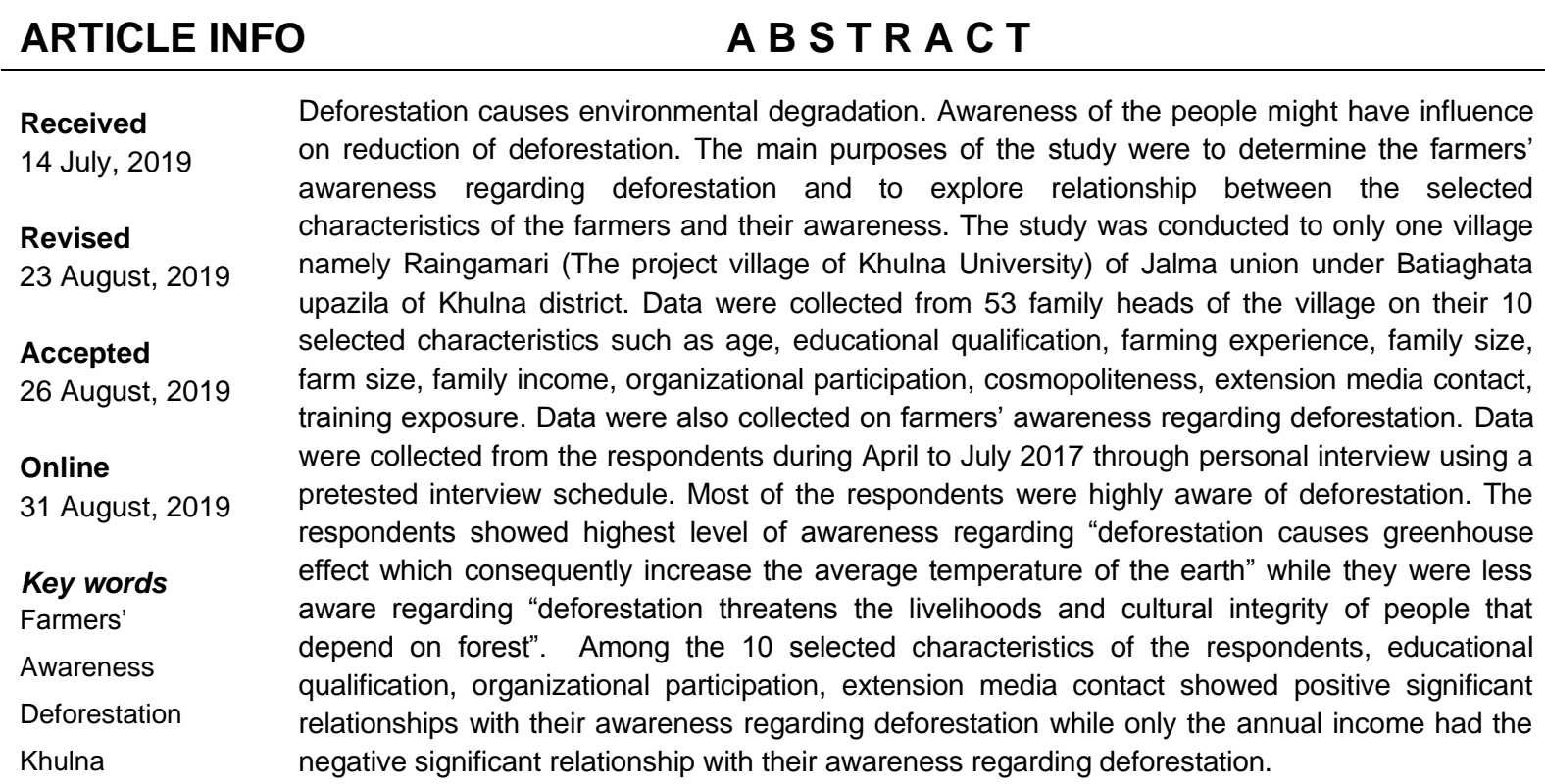

To cite this article: Mondol S, A Mollick, MB Ahmed and MM Islam, 2019. Farmers' awareness regarding deforestation at Jalma union of Batiaghata upazila under Khulna district of Bangladesh. Res. Agric. Livest. Fish. 6 (2): 193-202.

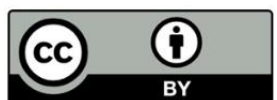

Copy right $\odot$ 2019. The Authors. Published by: AgroAid Foundation This is an open access article licensed under the terms of the Creative 


\section{INTRODUCTION}

Forest provides cover to the earth's land surface and many environmental benefits including a major role in the hydrologic cycle, soil conservation, and prevention of climate change and preservation of biodiversity (Ekhuemelo and Akeh, 2015). Forest resources can provide long-term national economic benefits. At least 145 countries of the world are currently involved in wood production (Anderson, 2006). Deforestation is known as forest decline, forest fragmentation and degradation, loss of forest cover, and land-use conservation. Deforestation is defined as clearing of any area of its natural vegetation cover, which normally leads to decrease in plants population resulting in loss of plant biodiversity (Aliyu et al., 2014). It is also defined as the indiscriminate felling of trees without their replacement (Mustapha et al., 2012). The contemporary world is facing an environmental crisis on account of heavy deforestation. For years, remorseless destruction of forest has been going on and we are unable to comprehend the dimension until recently. However, it is obvious that the area of tropical rainforest is diminishing and the rate of tropical rain forest destruction is escalating worldwide, despite increased environmental activism and awareness (Docena, 2010). According to Becek and Odihi (2008), human activities are globally recognized as the principal cause of deforestation. Several researches dealing with deforestation have been undertaken, focusing on both the microeconomic (Gillis, 1988 and Repetto, 1988) and macroeconomic causes of rapid deforestation in the tropics. However, the relevance of understanding the deforestation systems goes beyond the capability to point out the changes resulting from deforestation; it is necessary to realize its causes and effects on natural resources (Mena, 2001). Scientists generally mention population pressure and rural poverty as a key element in explaining deforestation of Bangladesh. However, other scientists and environmental groups have referred forest shrinkage to economic growth, national policies, and the harvesting of trees for firewood (Salam and Noguchi, 1998). Empirical support for these hypotheses is fundamentally applicable for all forest types of Bangladesh. Deforestation in Bangladesh is obviously a complex issue and, moreover, scanty scientific studies have been carried out to identify its deep causes (Safa, 2004).

According to the United Nation's Framework Convention on Climate Change (UNFCCC, 2010), the overwhelming direct cause of deforestation is agriculture; with subsistence farming responsible for $32 \%$, logging $14 \%$ and fire wood removal make up $5 \%$. Bangladesh has the worst deforestation rate in the world, which can be attributed to increase in population with high poverty level bulk of the population depend on forests for their energy needs (International Institute of Tropical Agriculture, 2011). In an attempt to reduce the effects of deforestation on livelihoods, farming households were compelled to develop some adaptation strategies, as farming households responds to changing environmental circumstances in a variety of ways. Thus, it is experiential that the survival attitudes caused by deforestation encouraged the development of local people consciousness about environment and its conservation (FAO, 2009). The systems such as agroforestry were more beneficial in comparison to producing only annual food crops or pasture, because agroforestry systems could generate income from tree sales and carbon trading programmes, such as reducing emissions from deforestation and degradation schemes. The Forestry Ministry arrange training programmes for different agroforestry types such as home types, where people plant and tend to trees around the home. "Home types are good because different types of plants - trees, shrubs, herbaceous plants - can be grown in or adjacent to a home compound, (Rahman, 2012). In addition, several efforts are being made by both the state and local governments towards reclaiming the various degraded and marginal lands in the various parts of the country. Such efforts are being implemented by the recently established Agency of Bangladesh. These strategies were all aimed at increasing global and national concerns in addressing the issues of deforestation. Therefore, it is clear that deforestation is the main cause of environmental degradation. In this regard, different afforestation and reforestation programme agroforestry programmed are a prime consideration to save the environment.

Considering the points in view the present study was undertaken with a view to study farmers' awareness regarding deforestation. The specific objectives of the study were to analyze the selected characteristics of the farmers and to determine farmers' awareness regarding deforestation. In addition, the relationship between the selected characteristics of the farmers and their awareness regarding deforestation was also assessed. 


\section{METHODOLOGY}

The present study is based on descriptive and diagnostic research design. The present study was based on collection of data by door to door interviewing. It was designed to study the farmer's awareness regarding deforestation in the Raingamari village (The project Village of Khulna University) of Jalma union under Batiaghata upazila of Khulna district. The Raingamari village was selected purposively as the locale of the study. The study area was selected due to its closeness/proximity with researchers dwelling or university. Raingamari is a small village and a number of 53 families live in the village (study area). The heads of the 53 families were considered as the population and sample for the study.

The personal and socio-economic characters of the respondents were treated as independent variables for the study. The characteristics were age, educational qualification, farming experience, family size, farm size, annual income, organizational participation, cosmopoliteness, extension media contact and training exposure. Farmers' awareness regarding deforestation was considered as dependent variable in this study.

To measure farmers' awareness regarding deforestation, a number of 6 statements related to harmful effects of deforestation and another 6 statements related to beneficial effect of afforestation. To determine the awareness score of the respondents a five point rating scale such as strongly agree, agree, undecided, disagree and strongly disagree were employed against the 12 statements. A score 5, 4, 3, 2 and 1 was employed against the scales respectively. The awareness score of a respondent was calculated by adding all the scores obtained by a respondent against the twelve $(6+6=12)$ statements. The awareness score of respondents could be ranged from 12-60, where ' 12 ' indicate less awareness and 60 indicate high awareness. Based on awareness score, the respondents were classified in to three categories as shown in Table 1. To compare among 12 statements related to harmful effects (6) of deforestation and beneficial effects (6) of afforestation an awareness index (Al) was calculated using following formula:

$A l=N_{\text {sag }} \times 5+N_{\text {ag }} \times 4+N_{\text {ud }} \times 3+N_{d a} \times 2+N_{\text {sda }} \times 1$

Where,

$\mathrm{Al}=$ Awareness Index

$\mathrm{N}_{\text {sag }}=$ Number of respondents rated the statement related to awareness as strongly agree

$\mathrm{Nag}_{\mathrm{ag}}$ Number of respondents rated the statement related to awareness as agree

$\mathrm{N}_{\mathrm{ud}}=$ Number of respondents rated the statement related to awareness as undecided

$\mathrm{N}_{\mathrm{da}}=$ Number of respondents rated the statement related to awareness as disagree

$\mathrm{N}_{\mathrm{sda}}=\mathrm{Number}$ of respondents rated the statement related to awareness as strongly disagree

The Al score of the respondents regarding a statement could range from ' 53 ' to ' 265 ' where ' 53 ' indicate less awareness and ' 265 ' indicate the high awareness.

For better understanding, the Al score was converted to percentage using following formula.

$$
\% \mathrm{AI}=\frac{\text { Observed AI score }}{\text { Possible AI score }} \times 100
$$

\section{RESULTS}

\section{Selected characteristics of the farmers}

The selected characteristics of the farmers are described in this section and a summary profile of these characteristics is presented in Table 2. Data presented in Table 2 indicate that majority (51\%) of the respondents was middle aged as compared to $41.50 \%$ young aged and $7.50 \%$ being old aged. Highest proportion $(32.10 \%)$ of the respondents had secondary level of education followed by primary $(22.60 \%) \&$ illiterate $(20.80 \%)$. Only a few $(13.20 \%$ and $11.30 \%)$ of the respondents having higher secondary and above higher secondary level of education, respectively. Similar findings were observed by Bene (2006) regarding education. Data computed in Majority of the respondents $(50.90 \%)$ had low farming experience followed by medium experienced (30.20\%) and had high experienced (18.90\%). Islam et al. (1998) found similar result on farming experience. Majority $(56.60 \%)$ of the respondents had medium sized family compared to small sized 
$(30.20 \%)$ and larger sized (13.20\%) family. The average family size (5.08) of the study area is higher than that of national average (4.4; BBS, 2013). It means that the people in the study area are not conscious about their family size and population growth.

Table 1. Categories of respondent farmers based on their awareness score

\begin{tabular}{|ll|}
\hline Categories & Score(s) \\
\hline Low awareness & $\leq 20$ \\
Medium awareness & $21-40$ \\
High awareness & $41-60$ \\
\hline
\end{tabular}

Table 2. Selected characteristics of the respondents

\begin{tabular}{|c|c|c|c|c|c|c|}
\hline \multirow{2}{*}{ Characteristics } & \multirow{2}{*}{ Range } & \multirow{2}{*}{ Category } & \multicolumn{2}{|c|}{ Respondents ( $\mathrm{N}=53)$} & \multirow[t]{2}{*}{ Mean } & \multirow{2}{*}{$\begin{array}{l}\text { Std. } \\
\text { Dev. }\end{array}$} \\
\hline & & & Number & $\%$ & & \\
\hline Age (year) & $25-60$ & $\begin{array}{l}\text { Young (up to } 35) \\
\text { Middle age (36-50) } \\
\text { Old (above } 50)\end{array}$ & $\begin{array}{l}22 \\
27 \\
4\end{array}$ & $\begin{array}{l}41.50 \\
51 \\
7.50\end{array}$ & 39.75 & 8.73 \\
\hline $\begin{array}{l}\text { Educational } \\
\text { Qualification } \\
\text { (year of schooling) }\end{array}$ & $0-14$ & $\begin{array}{l}\text { Illiterate }(0) \\
\text { Primary level }(1-5) \\
\text { Secondary level }(6-10) \\
\text { Higher secondary }(11-12) \\
\text { Above higher secondary (above 12) }\end{array}$ & $\begin{array}{l}11 \\
12 \\
17 \\
7 \\
6\end{array}$ & $\begin{array}{l}20.80 \\
22.60 \\
32.10 \\
13.20 \\
11.30\end{array}$ & 7.51 & 4.79 \\
\hline $\begin{array}{l}\text { Farming } \\
\text { experience (year) }\end{array}$ & $5-30$ & $\begin{array}{l}\text { Low (up to 10) } \\
\text { Medium (11-20) } \\
\text { High (above 20) }\end{array}$ & $\begin{array}{l}27 \\
16 \\
10\end{array}$ & $\begin{array}{l}50.90 \\
30.20 \\
18.90\end{array}$ & 14.25 & 7.68 \\
\hline $\begin{array}{l}\text { Family size } \\
\text { (number) }\end{array}$ & $3-9$ & $\begin{array}{l}\text { Small }(1-4) \\
\text { Medium (5-6) } \\
\text { Large (above 6) }\end{array}$ & $\begin{array}{l}16 \\
30 \\
7 \\
\end{array}$ & $\begin{array}{l}30.20 \\
56.60 \\
13.20 \\
\end{array}$ & 5.08 & 1.48 \\
\hline $\begin{array}{l}\text { Farm size } \\
\text { (hectare) }\end{array}$ & $\begin{array}{l}0.16- \\
5.02\end{array}$ & $\begin{array}{l}\text { Landless }(<0.02) \\
\text { Marginal }(0.02-0.20) \\
\text { Small }(0.21-1.0) \\
\text { Medium }(1.01-3.0) \\
\text { Large (above } 3.0)\end{array}$ & $\begin{array}{l}0 \\
3 \\
25 \\
20 \\
5\end{array}$ & $\begin{array}{l}0 \\
5.70 \\
47.20 \\
37.70 \\
9.40\end{array}$ & 1.51 & 1.13 \\
\hline $\begin{array}{l}\text { Annual income } \\
\text { (thousands) }\end{array}$ & $35-350$ & $\begin{array}{l}\text { Low (up to } 50) \\
\text { Medium }(51-100) \\
\text { High (above } 100)\end{array}$ & $\begin{array}{l}18 \\
28 \\
7\end{array}$ & $\begin{array}{l}34 \\
52.80 \\
13.20\end{array}$ & 87.49 & 64.43 \\
\hline $\begin{array}{l}\text { Organizational } \\
\text { participation } \\
\text { (score) }\end{array}$ & $0-3$ & $\begin{array}{l}\text { No participation (0) } \\
\text { Low (1-2) } \\
\text { Medium (3-4) } \\
\text { High (above 4) }\end{array}$ & $\begin{array}{l}17 \\
34 \\
2 \\
0\end{array}$ & $\begin{array}{l}32 \\
64.20 \\
3.80 \\
0\end{array}$ & 1.08 & 0.90 \\
\hline $\begin{array}{l}\text { Cosmopoliteness } \\
\text { (score) }\end{array}$ & $0-12$ & $\begin{array}{l}\text { No }(0) \\
\text { Low }(1-5) \\
\text { Medium }(6-10) \\
\text { High (above 10) }\end{array}$ & $\begin{array}{l}2 \\
32 \\
17 \\
2\end{array}$ & $\begin{array}{l}3.80 \\
60.40 \\
32 \\
3.80\end{array}$ & 4.96 & 2.44 \\
\hline $\begin{array}{l}\text { Extension media } \\
\text { contact (score) }\end{array}$ & $8-50$ & $\begin{array}{l}\text { Low (1-20) } \\
\text { Medium (21-40) } \\
\text { High (above 40) } \\
\end{array}$ & $\begin{array}{l}30 \\
20 \\
3 \\
\end{array}$ & $\begin{array}{l}56.60 \\
37.70 \\
5.70 \\
\end{array}$ & 21.49 & 9.29 \\
\hline Training exposure & $0-2$ & $\begin{array}{l}\text { No (0) } \\
\text { Low (1) } \\
\text { Medium (2) } \\
\text { High (above 3) }\end{array}$ & $\begin{array}{l}38 \\
13 \\
2 \\
0\end{array}$ & $\begin{array}{l}71.70 \\
24.50 \\
3.80 \\
0\end{array}$ & 0.32 & 055 \\
\hline
\end{tabular}


The data presented in Table 2 indicated that highest proportion (47.20\%) of the respondents had small farm holdings compared to medium (37.70\%), large $(9.40 \%)$ and marginal $(5.70 \%)$ farm holdings. Hamid (1995) found similar result on farm size. Majority $(52.80 \%)$ of the respondents belonged to medium income group as compared to low (34\%) and high (13.20\%) income groups. Zaidi et al. (2011) found similar results on respondents' family income.

Majority (64.20\%) of the respondents had low organizational participation as compared to no participation $(32 \%)$ and medium (3.80\%). The findings of the present study have harmony with the findings of Hamid (1997) and Hossain (1999) regarding organizational participation of the respondents. Majority $(60.40 \%)$ of the respondents had low cosmopoliteness as compared to medium (32\%) and no cosmopoliteness. Only a few (3.80\%) had high cosmopoliteness. Khan and Hamid (1995) found similar results related to cosmopoliteness of the respondents. Data presented in Table 2 also indicate that majority (56.60\%) of the respondents had low extension media contact while $37.70 \%$ of them had medium and $5.70 \%$ had high extension media contact. Miah and Rahman (1995), Hanif (2000), Hossain (1999) also found similar result about extension media contact of the respondents. Majority $(71.70 \%)$ of the respondents had no training exposure. However, about one-fourth $(24.50 \%)$ of the respondents had low training and a very few $(3.80 \%)$ had medium training exposure. World Bank (WB, 2006) reported that only $4 \%$ of farmers were properly trained on environmental degradation.

\section{Farmers' Awareness regarding Deforestation}

The awareness regarding deforestation scores of the farmers varied from 39 to 58 being mean and standard deviation of 49.42 and 4.50 respectively. The respondents were classified into three categories based on their awareness scores. The categories and distribution of the farmers are shown in Table 3.

Table 3. Distribution of the respondents according to their awareness

\begin{tabular}{|c|c|c|c|c|c|c|c|}
\hline \multirow{2}{*}{ Categories } & \multirow{2}{*}{ Score } & \multicolumn{2}{|c|}{ Respondents ( $\mathrm{N}=53$ ) } & \multirow{2}{*}{ Mean } & \multirow{2}{*}{$\begin{array}{l}\text { Standard } \\
\text { Deviation }\end{array}$} & \multirow{2}{*}{ Min. } & \multirow{2}{*}{ Max. } \\
\hline & & Number & Percentage & & & & \\
\hline $\begin{array}{l}\text { Low } \\
\text { awareness }\end{array}$ & $\leq 20$ & 0 & 0 & & & & \\
\hline Medium & $21-40$ & 2 & 3.8 & & & & \\
\hline awareness & & & & 49.42 & 4.50 & 39 & 58 \\
\hline $\begin{array}{l}\text { Higher } \\
\text { awareness }\end{array}$ & $41-60$ & 51 & 96.2 & & & & \\
\hline Total & & 53 & 100 & & & & \\
\hline
\end{tabular}

Source: Field Survey, 2017

Data contained in Table 3 indicate that most (96.20\%) of the respondents had high awareness while $3.80 \%$ respondents had medium awareness regarding deforestation. It means that all most all of the respondents of the study area are highly aware regarding deforestation (the environment). Mustafha et al. (2012) and Hanif (2000) almost found similar types of result in this regard. Mustapha et al. (2012) observed in their study that most (86.7\%) of the respondents had more adaptation to deforestation while $13.3 \%$ had less adaptation to deforestation. The adaptations of the respondents indicate their awareness. Hanif (2000) in his study indicated that among the Farmers Field School (FFS) farmers, 100\% had high awareness on environmental pollution due to use of pesticide. In case of Non-FFS farmers, $66.67 \%$ had poor awareness, while $30 \%$ had medium and $3.33 \%$ had high awareness on environmental pollution due to use of pesticides. Deforestation is considered one of the oldest problems of the world, and it is as old as the agricultural revolution 10,000 to 12,000 years ago (Mena, 2001). People have always needed land for their own uses and have consequently cleared natural vegetation. Nowadays, global deforestation is understood to be one of the key problems of climate change (Gorte and Sheikh, 2010). Moreover, the economic value of natural resources, such as forests, has been shown to be the major cause of deforestation in developing countries 
(Munasinghe, 1993). About $50 \%$ of the original forest covering our globe has been cleared in the last 40 years (FAO, 1995 and WWF, 1998) and in developing countries about 1.5 billion people rely on firewood for cooking and heating (Tucker, 1999).

Bangladesh is a developing country having 14.4 million hectares of total geographic area (Islam, 2005). Of them, 13.36 million hectares are land surface, and 0.94 million hectares are rivers and other inland water bodies (BBS, 2001). The country has only $17.08 \%$ (2.52 million ha) of total forest land (GOB, 2010). A few decades ago, Bangladesh was rich in forest resources but a rapid population growth, land conversion into different commercial activities, increased consumption of energy and wood and maximum utilization of natural resources have led to a rapid degradation of forest resources (Alam et al., 2008). The tropical moist deciduous Sal forests are a leading example of such degradation (Ali et.al, 2006), due to highly increasing population that have sequentially brought exploitation of the forest at a significant rate, nearly close to destruction (Alam et al., 2008; Safa, 2004).

\section{Comparison among 12-statements related to farmers' awareness regarding deforestation}

Comparison among 12-statements related to farmers' awareness regarding deforestation was done based on awareness index. The statements were ranked based on awareness index which is shown in Table 4. Data presented in Table 4 indicate that among 12 statements related to awareness of deforestation, the respondents showed highest level of awareness about "deforestation causes greenhouse effect which consequently increase the average temperature of the earth $(A I=242$, ranked $=01)$ while it was least about "deforestation threatens the livelihoods and cultural integrity of people that depend on forest" $(\mathrm{Al}=183$, ranked $=12$ ).

Table 4. Rank order of the statements related to the farmers' awareness regarding deforestation in the study area based on awareness index

\begin{tabular}{|c|c|c|c|c|}
\hline \multirow{2}{*}{$\begin{array}{l}\text { SI. } \\
\text { No. }\end{array}$} & \multirow{2}{*}{ Statements } & \multicolumn{2}{|c|}{ Awareness Index (Al) } & \multirow{2}{*}{ Rank order } \\
\hline & & Score & Percent & \\
\hline 1. & $\begin{array}{l}\text { Deforestation causes greenhouse effect to increase the } \\
\text { average temperature of the earth }\end{array}$ & 242 & 91.32 & $1^{\text {st }}$ \\
\hline 2. & $\begin{array}{l}\text { Deforestation causes soil erosion and also reduce soil } \\
\text { fertility }\end{array}$ & 237 & 89.43 & $3^{\text {rd }}$ \\
\hline 3. & Deforestation decreases the general biodiversity. & 216 & 81.50 & $7^{\text {th }}$ \\
\hline 4. & Deforestation helps in spreading disease. & 184 & 69.43 & $11^{\text {th }}$ \\
\hline 5. & $\begin{array}{l}\text { Deforestation increases the likelihood of natural } \\
\text { hazards- storm, floods and extreme fluctuations in } \\
\text { weather. }\end{array}$ & 223 & 84.15 & $6^{\text {th }}$ \\
\hline 6. & $\begin{array}{l}\text { Deforestation threatens the livelihoods and cultural } \\
\text { integrity of people that depend on forest. }\end{array}$ & 183 & 69.05 & $12^{\text {th }}$ \\
\hline 7. & Afforestation is useful to protect the wild life. & 233 & 87.92 & $4^{\text {th }}$ \\
\hline 8. & $\begin{array}{l}\text { Planting of trees simply restores \& maintains ecological } \\
\text { balance of all systems in the environment. }\end{array}$ & 213 & 80.37 & $9^{\text {th }}$ \\
\hline 9. & Trees bring soils together which prevents erosion. & 231 & 87.17 & $5^{\text {th }}$ \\
\hline 10. & Afforestation increases food \& fodder production. & 240 & 90.57 & $2^{\text {nd }}$ \\
\hline 11. & Afforestation helps in avoiding desertification. & 204 & 76.98 & $10^{\text {th }}$ \\
\hline 12. & $\begin{array}{l}\text { Afforestation helps in preventing further global warming } \\
\text { and reversing the effects of global warming. }\end{array}$ & 215 & 81.13 & $8^{\text {th }}$ \\
\hline
\end{tabular}

Source: Field Survey, 2017 
Table 5. Relationship between the selected characteristics of the farmers and their awareness regarding deforestation

\begin{tabular}{|l|l|l|}
\hline Independent variable & Dependent variable & Correlation coefficient \\
\hline Age & \multirow{3}{*}{$\begin{array}{l}\text { Farmers awareness regarding } \\
\text { deforestation }\end{array}$} & $-0.147 \mathrm{NS}$ \\
\cline { 1 - 1 } & & $0.382^{* *}$ \\
\cline { 1 - 1 } Farming Experience & & $0.094 \mathrm{NS}$ \\
\hline Family Size & & $-0.178 \mathrm{NS}$ \\
\hline Farm Size & & $0.015 \mathrm{NS}$ \\
\hline Annual income & & $-0.502^{* *}$ \\
\cline { 1 - 1 } Organizational participation & & $0.483^{* *}$ \\
\hline Cosmopoliteness & & $0.208 \mathrm{NS}$ \\
\hline Extension media contact & & $0.357^{* *}$ \\
\hline Training exposure & & $0.187 \mathrm{NS}$ \\
\hline
\end{tabular}

Source: Field Survey, 2017

NS= Non-significant, ${ }^{*}$ Correlation highly significant at $5 \%$ level of probability

\section{Relationship between the selected characteristics of the farmers and their awareness regarding deforestation}

Out of ten selected characteristics of the respondent farmers, educational qualification, organizational participation, extension media contact showed positive significant relationships with their awareness regarding deforestation while only annual income showed negative significant relationship. It means that the higher is the educational qualification, organizational participation and extension media contact, the higher is the awareness of the farmers regarding deforestation. On the other hand, the higher is the annual income; the lower is the awareness of the farmer's regarding deforestation. Similar results were also found by Shrestha (2010) and Islam (2009) regarding educational qualification and organizational participation. The findings of the studies conducted by Hamid (1997), Hanif (2000), Hossain (1999), Miah and Rahman (1995), Sarker (1999) have harmony with the present study regarding extension media contact. The findings of Parveen (1995) were also similar regarding annual income.

\section{DISCUSSION}

Every year, about 13 million hectares of forest are converted to other land uses (FAO, 2010), leading to biodiversity losses, soil erosion, and massive carbon dioxide (CO2) emissions. At the same time, demand for timber products is rapidly increasing, especially in the developing world. FAO (2009) projection mentioned an annual worldwide increase of $1.5 \%$ of saw wood consumption, $3.3 \%$ of wood-based panels and $3 \%$ of paper for the 2005-2020, period. Agricultural expansion is the major cause of deforestation. Indeed about $70 \%$ of the total deforestation in the 1990s was credited to agricultural expansion (Eleri et al., 2012). Over the years, sustainable management of forest resources has been of primary concern due to its potentials impact on biological diversity and importance in maintaining global ecological function as cited by (Adefila and Madaki, 2014). There are different ways of adapting to deforestation in agriculture among which include; crop diversification, mixed crop-livestock farming systems, use of alternative sources of energy, domestication of medicinal plants, conservative agriculture, using different crop varieties, changing planting and harvesting dates, and mixing less productive, drought resistant varieties and high-yield water sensitive crops are among the important adaptation options that farmers uses. 
In spite of its importance, the natural tropical forest continued to diminish rapidly in the Asian continent, thus leading to dwindling sustainable forest management. "Deforestation has reached an alarming rate in recent years. If no changes occur, Bangladesh will have no forest left," (Rahman, 2012). "There are many good policies in Bangladesh but they are not being carried out. They need to be strengthened and better enforced." To combat the emerging environmental problems many nations across the globe have been involved in afforestation and reforestation on the already deforested and un-utilized lands. In Bangladesh, a programme like this should prioritize its agroforestry policies, (Rahman, 2012). "The most effective way to reduce deforestation is through agroforestry. It could bring 'win-win' solutions to meet both environment and development objectives".

BFD is responsible for administering $65 \%$ of state forest land (about 1.46 million ha).The balance comes under local District Commissioners. Excluding parks and sanctuaries, but including the better quality natural forest (medium to good density) plus bamboo areas and plantations gives a figure of 835,000 ha of reasonable quality forest vegetation on state forest land. This equals $5.8 \%$ of Bangladesh's total area. The area included in the present protected area network is 116,700 ha, equal to $5.2 \%$ of state forest land or less than $1 \%$ of Bangladesh's total area (APFSOS, 1998).

\section{CONCLUSION}

Most of the respondents are highly aware of deforestation. The respondents showed highest level of awareness regarding "deforestation causes greenhouse effect which consequently increase the average temperature of the earth" while less aware regarding "deforestation threatens the livelihoods and cultural integrity of people that depend on forest". Among the selected characteristics of the respondents, educational qualification, organizational participation, extension media contact showed positive significant relationships with their awareness regarding while only the annual income had the negative significant relationship with their awareness regarding deforestation. Finally we can say that farmers in the study area quite aware of the risks associated with deforestation and its effects on the environment.

\section{ACKNOWLEDGEMENT}

The researchers wholeheartedly acknowledge the immense contribution made by the respondent farmers by providing information regarding deforestation who were the inhabitants of the Raingamari village (The project Village of Khulna University) of Jalma union under Batiaghata upazila of Khulna district.

\section{COMPETING INTERESTS}

Authors have declared that no competing interests exist.

\section{REFERENCES}

1. Adefila, J.O. and Madaki, J. 2014. Role of farmers Cooperatives in Agricultural Development in Sabuwa Local Government Area of Katsina State, Nigeria.Journal of Economics and Sustainable Development, 5(12): 305-316.

2. Alam, M., Furukawa, Y., Sarker, S.K. and Ahmed, R. 2008. Sustainability of Sal (Shorea robusta) Forest in Bangladesh: Past, Present and Future Actions. International Forestry Review 10 (1): 29-37.

3. Ali, M., Kabir, M.A. and Hoque A.T.M.R. 2006. People, policy and perpetuity: sustainability indicators of Bangladesh forestry. Electronic Green Journal, 1(24): 201-225.

4. Aliyu, A., Modibbo, M.A., Medugu, N.I and Ayo, O. 2014. Impact of deforestation on socio-economic development of Akwanga Nassarawa State. International Journals of Science, Environment and Technology, 3(2): 403-416. 
5. Anderson, E. 2006. Urban Landscape and Sustainable Cities: Ecology and Society. From <http://www.ecology and society.org/vol11/issl/art34/.2006.

6. BBS (Bangladesh Bureau of Statistics). 2001. Statistical Year Book of Bangladesh. Bangladesh Bureau of Statistics, Government of People's Republic of Bangladesh, Dhaka, Bangladesh.

7. BBS (Bangladesh Bureau of Statistics). 2013. Statistical Yearbook of Bangladesh, Ministry of Planning, Government of Bangladesh.

8. Becek and Odihi, J.O. 2008. Identification and Assessment of Factors Affecting Forest Depletion in Brunei Darussalam. The International Archives of the Photogrammetry, Remote Sensing and Spatial Information Sciences xxxvii (B2): 209-214.

9. Bene, J.F.H. 2006. Environmental Awareness of Rural People in Their Farm and Homestead Activities. An M.S. (Ag. Ext. Ed.) Thesis, Department of Agricultural Extension Education, Bangladesh Agricultural University, Mymensingh.

10. Docena, H. 2010. Philippnes: Deforestation through Mining Subsidized by CDM Project. WRM's Bulletin No. 161.

11. Ekhuemelo, D.O. and Akeh, F. 2015. Survey of Afforestation Efforts between 2010 - 2014 in Makurdi Local Government Area of Benue State, Nigeria. Nigeria Journal of Agriculture, Food and Environment, 11(2): 97-102.

12. Eleri, B.O., Ugwu O. and Onuvae P. 2012. Expanding Access to Pro-poor Energy Services in Nigeria. A Consultation Paper prepared by International Centre for Energy, Environment and Development (ICEED) with support from Christian Aid.

13. FAO (Food and Agriculture Organization) of United Nation. 2009. Tree Planting Practice in African Savanna Forestry Paper FAO Rome, pp: $170-185$.

14. FAO (Food and Agriculture Organization). 1995. Forest Resources Assessments 1990: Global Synthesis: FAO Forestry Paper, 124, Rome, Italy.

15. FAO (Food and Agriculture Organization). 2010. Sustainable Crop Production Intensification through an Ecosystem Approach and an Enabling Environment: Capturing Efficiency through Ecosystem Services and Management. 22nd Session of the FAO Committee on Agriculture, Rome.

16. Gillis, M. 1988. West Africa: Resource Management Policies and the Tropical Forest. In: "Public Policies and the Misuse of Forest Resources" (Repetto R, Gillis M eds). Cambridge University press, Cambridge, UK, pp. 299-352.

17. GOB. 2010. Forest Department Official Website. Government of People's Republic of Bangladesh, Dhaka, Bangladesh.

18. Gorte, R.W. and Sheikh, P.A. 2010. Deforestation and Climate Change. CRS Report.

19. Hamid, M.A. 1995. Farmers Awareness on Environmental Pollution Caused by the Use of Agrochemicals in Two Selected Villages of BAU Extension Centre.An M.S. (Ag. Ext. Ed.) Thesis, Department of Agricultural Extension Education, Bangladesh Agricultural University, Mymensingh.

20. Hamid, M.A. 1997. Farmers' Awareness on Environmental Pollution: A Study in Bangladesh. Asia Pacific Journal of Rural Development, 7(2): 107-111.

21. Hanif, M.A. 2000. Competitive Analysis between FFS and Non-FFS Farmers Regarding Environmental Awareness.An M.S. (Ag. Ext. Ed.) Thesis, Department of Agricultural Extension Education, Bangladesh Agril. Univ. Mymensingsh, pp. 68-74.

22. Hossain, M.S. 1999. Farmers' Perception on the Effects of Agro-Chemicals on Environment. An M.S. (Ag. Ext. Ed.) Thesis, Department of Agricultural Extension Education, Bangladesh Agricultural University, Mymensingh. pp. 85-90.

23. IITA, 2011. Deforestation: Nigeria Ranked Worst in the World. A publication of International Institute of Tropical Agriculture. http://www.thisdaylive.com/articles/deforestation-Nigeria-ranked-worst-in-the world/103321.

24. Islam, K.S. and Amin, N. 2009. Knowledge on Environment of Farmers on the use of Modern Agricultural Technologies. International Journal of Sustainable Agricultural Technology, 5(7): 36-41.

25. Islam, M.N., Ahmed, M.B. and Akanda, M.G.R. 1998. Farmers' Awareness on the Environmental Pollution. Bangladesh Journal of Training and and Development, 11(1\&2): 33-38. 
26. Islam, N. 2005. Environmental Issue in Bangladesh: an Overview. Pakistan Journal of Social Science 3: 671-679.

27. Mena, C.F. 2001. Deforestation in the Napo Basin: Socio-Economic Factors, Metrics, and Patterns. M.Sc. Dissertation, Environmental Studies Department, Florida International University, Miami, FL, USA.

28. Miah, M.A.M. and Rahman, M.M. 1995. Farmers' Awareness Regarding Changes in the Farming Environment. Bangladesh Journal of Agricultural Sciences 5(3): 96-99.

29. Munasinghe, M. 1993. Environmental Economics and Biodiversity Management in Developing Countries. Ambio, 22: 126-135.

30. Mustapha, S.B. Bzugu, P.M. Ali, I.M. and Abdullahi, A. 2012. Determinant of Adaptation to Deforestation among Farmers in Madagali Local Government Area of Adamawa State, Nigeria. Russian Journal of Agricultural and Socio-Economic Sciences, No. 8(8).

31. Parveen, S. 1995. Awareness of Farm Women on Environmental Degradation due to the Use of Some Selected Modern Agricultural Technologies. An M.S. (Ag. Ext. Ed.) Thesis, Department of Agricultural Extension Education, Bangladesh Agril. Univ., Mymensingh, p.112.

32. Repetto, R. 1988. Needed: New Policy Goals. American Forests, 94: 58-64.

33. Safa, M.S. 2004. The Effect of Participatory Forest Management on the Livelihood of the Settlers in a Rehabilitation Program of Degraded Forest in Bangladesh. Small-scale Forest Economics, Management and Policy, 3(2): 223-238.

34. Salam, M.A. and Noguchi, T. 1998. Factors Influencing the Loss of Forest Cover in Bangladesh: an Analysis from Socio-Economic and Demographic Perspectives. Journal of Forestry Research 3: 145 150.

35. Sarker, R.C. 1999. Farmers' Awareness Regarding Environmental Degradation due to the Use of Agro- Chemicals. An M.S. (Ag. Ext. Ed.) Thesis, Department of Agricultural Extension Education, Bangladesh Agricultural University, Mymensingh, pp. 58-62.

36. Shrestha, R.K. 2010.Fertilizer Policy Development in Nepal. Journal of Agriculture and Environment.11:126-137.

37. Syed Ajijur Rahman. 2012. A Center for International Forestry Research Scientist and Coauthor of a New Journal Article titled Extent and Consequences of Tropical Forest Degradation: Successive Policy Options for Bangladesh.

38. Tucker, M. 1999. Can Solar Cooking Save the Forest? Ecological Economics, 31:77-89.

39. UNFCCC (United Nation's Framework Convention on Climate Change). 2010. Glossary of Climate Change Acronyms.

40. World Bank, 2006. Toxic Pollution from Agriculture- An Emerging Story. Research in Vietnam and Bangladesh Sheds New Light on Health Impacts of Pesticides. Available from: http:// go. World Bank.Org/ KN1TB1MO10.

41. WWF. 1998. Living Planet Report 1998: Overconsumption is driving the Rapid Decline of the World's Natural Environments. WWF, Gland, Switzerland.

42. Zaidi, A.A. Elhag, E.A. Otaibi, S.H. and Baig, M.B. 2011. Negative Effects of Pesticides on the Environment and the Farmers' Awareness in Saudi Arabia: a Case Study. JAPS, Journal of Animal and Plant Sciences, 21(3): 605-611. 